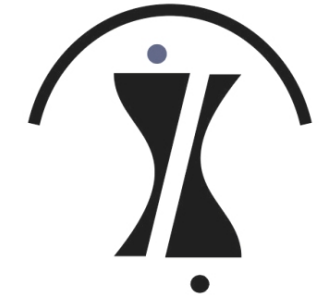

P R O B L E M S OF MANAGEMENT IN $\bullet$ THE $21 \mathrm{st}$ C E N T U R Y

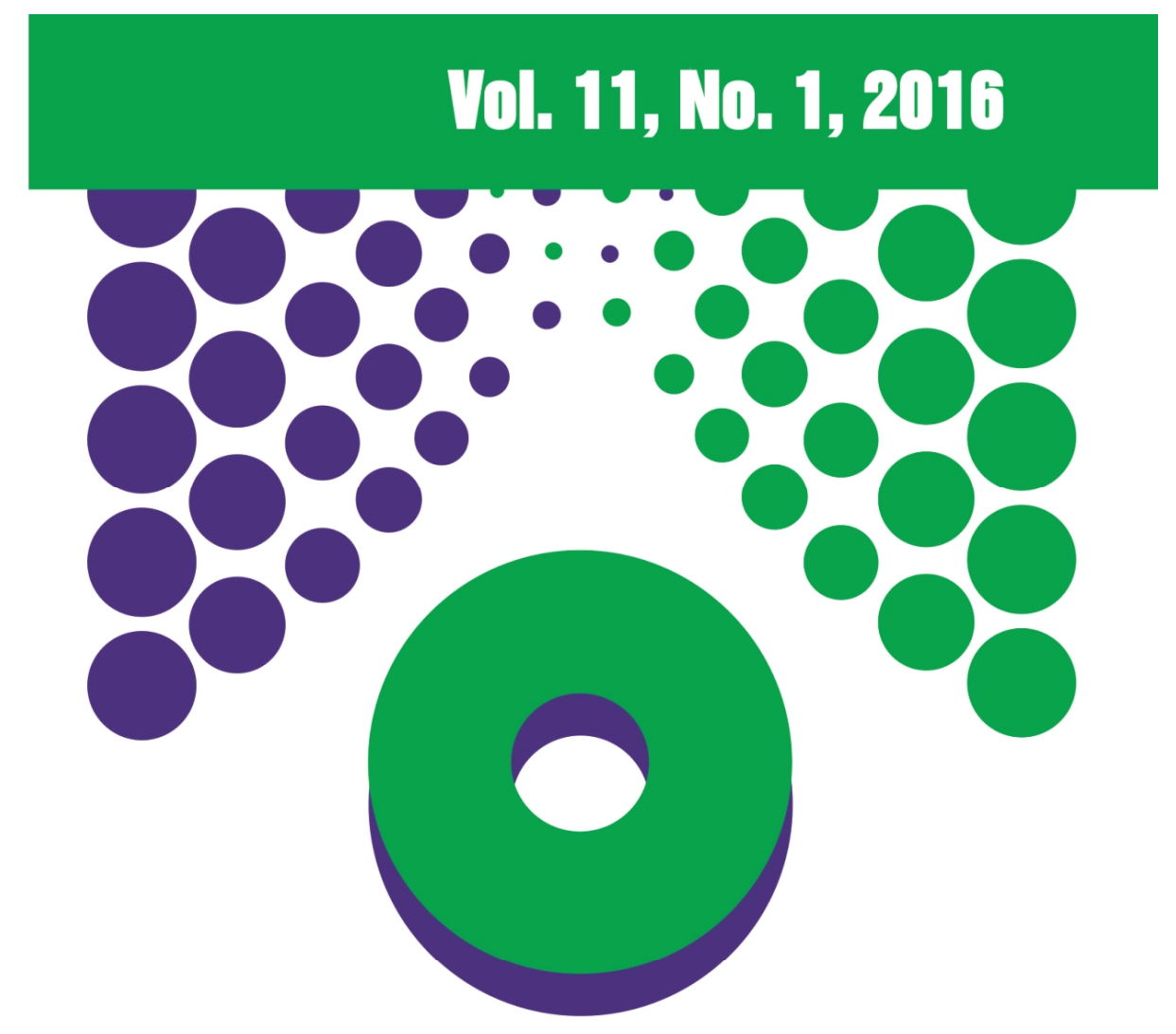

\title{
Problems of Management in the 21st Century
}

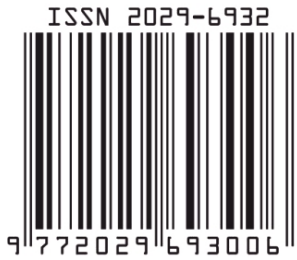


Vol. 11, No. 1, 2016

ISSN 2029-6932

\section{PROBLEMS OF MANAGEMENT IN THE 21 ${ }^{\text {ST }}$ CENTURY}

Scientific Methodical Center „Scientia Educologica“, Lithuania,

The Associated Member of Lithuanian Scientific Society, the Association of Lithuanian Serials, ESHS (European Society for the History of Science), and ICASE (International Council of Associations for Science Education)

The articles appearing in this scientific journal are indexed, liste and abstracted in:

Index Copernicus

EBSCO: Business Source Complete

EBSCO: Business Source Elite

EBSCO: Business Source Corporate

Cabell Publishing, Inc., Directory of Publishing

Opportunities in Management

Contemporary Science Association/AAP databases -

TOC Premier (EBSCO list)

The Wroblewski Library of the Lithuanian Academy of Sciences

PECOB (Portal on Central Eastern and Balkan Europe)

GESIS SocioGuide (Knowledge Base SSEE)

Genamics JournalSeek

Electronic Serials in Lithuania

trueserials.com

Universe Digital Library (UDL)

Ulrich's Periodicals Directory / Global Serials

Directory

Directory of Research Journal Indexing (DRJI)
Zeitschriftendatenbank $(Z D B)$

Academic Keys

Global Impact Factor (GIF)

Sjournals Index

Open Academic Journals Index (OAJI)

Scientific Indexing Services (SIS)

Pak Academic Search

Directory of Abstract Indexing for Journals (DAIJ)

Scholar Steer

Included into a List of Journals Recognized by Polish Ministry of Science and Higher Education

CNKI (China National Knowledge Infrastructure)

Scholar

Polish Scholarly Bibliography /PBN/ (Polska

Bibliografia Naukowa)

ImpactFactor.pl

European Reference Index for the Humanities and the

Social Sciences (ERIH PLUS)

Eurasian Scientific Journal Index (ESJI) 


\section{Publisher}

Scientific Methodical Center „Scientia Educologica“, Lithuania, the Associated Member of Lithuanian Scientific Society, the Association of Lithuanian Serials, European Society for the History of Science (ESHS) and International Council of Associations for Science Education (ICASE)

\section{Editor-in-Chief}

Prof. Dr. Vincentas Lamanauskas, University of Šiauliai \& Scientific Methodical Centre „Scientia Educologica“, Republic of Lithuania

\section{Editorial Board}

Prof., Dr. Constantin Bratianu, Academy of Economic Studies, Romania Dr. Luca Bussotti, International Studies Center of ISCTE, Portugal Dr. Camille Carbonnaux, University of Lille Nord de France, France Assoc. Prof., Dr. Tsai-Hsin Chu, National Chiayi University, Taiwan Dr. Iwona Gorzeń-Mitka, Czestochowa University of Technology, Poland Assoc. Prof., Dr. Dana Egerova, University of West Bohemia, Czech Republic Dr. Grzegorz Michalski, Wroclaw University of Economics, Poland Dr. Jorge Lima de Magalhães, Oswaldo Cruz Foundation/FIOCRUZ, Brazil Prof., Dr. Ivars Muzis, Riga Teacher Training and Educational Management Academy, Latvia Prof., Dr. Stephen Nzuve, University of Nairobi, Kenya Asst. Prof., Dr. Ivona Orzea, Academy of Economic Studies, Romania Prof., Dr. Sonia Teresinha de Sousa Penin, University of Sao Paulo, Brazil Prof., Dr. Chris Rensleigh, University of Johannesburg, South Africa Asst. Prof., Dr. Nikhil Chandra Shil, American International University, Bangladesh

Copyright of this issue is the property of Scientific Methodical Centre "Scientia Educologica" and Scientia Socialis, Lithuania. By virtue of their appearance in this open access journal, articles are free to use, with proper attribution, in educational and other non-commercial settings.

Index Copernicus (ICTM Value): 5.09 (2011), 79.14 (2014) (standardized value: 7.54). Global Impact Factor (GIF): 0.234 (2012), 0.342 (2013), 0.453 (2014), 0.564 (2015).

Problems of Management in the 21st Century is an international, periodical, peer reviewed scientific journal, issued by the SMC „Scientia Educologica“ in Cooperation with Scientia Socialis.

Address: Scientific Methodical Center "Scientia Educologica"

Donelaičio Street 29, LT-78115 Siauliai, Lithuania

E-mail: problemsofmanagement@gmail.com

Phone: +370 68795668

Webpages: http://www.jbse.webinfo.lt/PMC/Problems_of_Management.htm

http://www.scientiasocialis.lt/pmc/ 